\title{
ACRL honors the 2017 award winners, part 1 \\ A recognition of professional development
}

\section{Mark Sandler wins Hugh C. Atkinson Memorial Award}

Mark Sandler, principal at Novel Solutions Consulting, has been named the winner of the Hugh C. Atkinson Memorial Award.

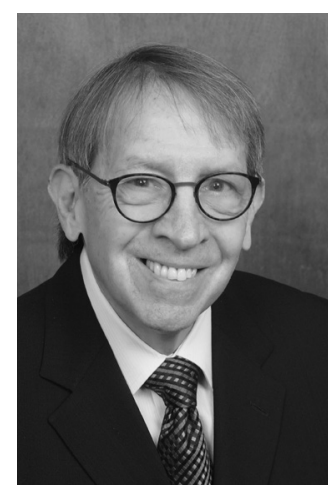

Mark Sandler
Sandler will receive a cash award and citation during the ALA Annual Conference in Chicago.

Named in honor of one of the pioneers of library automation, the Atkinson Award recognizes an academic librarian who has made significant contributions in the

area of library automation or management and has made notable improvements in library services or research.

"Dr. Mark Sandler is a library leader of great vision whose innovative ideas and persuasive skills carried to fruition two of the most impactful initiatives in the history of digitization," said Mark Stover, Hugh C. Atkinson Memorial Award Committee chair and dean of the Oviatt Library at California State University-Northridge.

"His founding of the Text Creation Partnership brought together a number of academic libraries with ProQuest, and this collaboration produced the seminal Early English Books Online database. Mark also championed the Google Book Digitization Project among the member libraries of the influential Big Ten Academic Alliance, thus greatly expanding the corpus of digitized books for both the Google project and the HathiTrust repository."

During his long career, Mark was known for his effectiveness as a negotiator, his uncanny ability to bring about consensus on contentious issues, his collaborative professional relationships, his strategic vision, and his far-reaching ideas," continued Stover. "From his early arguments in favor of cooperative collection development to his unwavering commitment to the ideal of digitizing all U.S. federal documents, Mark Sandler has left his imprint on the world of academic libraries like no one else."

It is a tribute to his wide-ranging influence that 12 diverse luminaries of the library world wrote detailed letters supporting his nomination, including several university library deans, the head of a major academic library consortium, a library school faculty member, the vice president of an important library technology vendor, and the executive director of the HathiTrust," Stover added. "Mark Sandler is, for all the reasons stated above, this year's highly deserving recipient of the Hugh C. Atkinson Award."

The Hugh C. Atkinson Award is jointly sponsored by four ALA divisions: ACRL, the Association for Library Collections and Tech-

Chase Ollis is ACRL program officer, email: collis@ala.org () 2017 Chase Ollis 


\section{Parham named Academic/Research Librarian of the Year}

Loretta Parham, CEO and director of the Atlanta University Center (AUC) Robert W. Woodruff Library, is the 2017 ACRLAcademic/Research Librarian of theYear.The award,sponsored by GOBI Library Solutions from EBSCO, recognizes an outstanding member of the library profession who has made a significant national or international contribution to academic/research librarianship and library development.

Parham received a \$,000 award during the Middle Keynote session on March 23, at the ACRL 2017 Conference in Baltimore.

"Loretta Parham's drive, activism, and innovative approaches to library transformation have had a broad and sustained impact well beyond our field, and she is the absolute embodiment of the ACRL Academic/Research Librarian of theYearAward," said Michael Courtney, chair of the ACRL Academic/ Research Librarian of the Year Award Committee and outreach

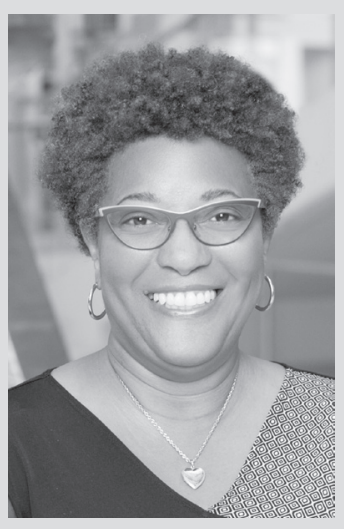

Loretta Parham visionary spirit of today's academic and research librarians," noted ACRL Executive Director Mary Ellen K.Davis."Widely recognized as a passionate advocate for libraries and librarians, her commitment to a transformational vision of the academic library as a center for research, learning, and outreach has earned her the respect of the institutions she serves, the library and higher education communities, and indeed, the general public."

Parham has personally served as a mentor to hundreds of librarians and is the co-founding director and founding Board chair of the HBCU (Historically Black Colleges and Universities) Library Alliance.

Established in 2002, the Alliance is a consortium of White Housedesignated HBCUs with a mission to transform its membership by developing leaders, preserving collections, and planning for the future. Due to Parham's leadership, the Alliance has been the recipient of or project partner in severalAndrew W. and engagement librarian at the Indiana University Libraries.

"This award is such an honor, and I am tremendously grateful for this acknowledgment of my passion and career commitment to service, libraries, and learning,"Parham said."The credit for these successes should be shared by many others with whom I have worked, and to each of them and ACRL I say thank you."

Highly respected by the library and higher education communities,Parham tirelessly worked to transform the Robert W. Woodruff Library, shared by Clark Atlanta University, the Interdenominational Theological Center, Morehouse College, and Spellman College, into a modern 21stcentury research facility known for its distinctive spaces and service.

Parham also expanded the library's stewardship of historically significant special collections. Among these is the Morehouse College Martin Luther KingJr.Collection,acquired by Morehouse in 2006 and housed in the Woodruff Library.

"Loretta Parham epitomizes the innovative,
Mellon Foundation grants awards strengthening library services related to leadership development, photographic preservation, digitization services, and library support of faculty services.

An active member of ALA and ACRL, Parham served as a member of the ACRL Board of Directors as director-at-large (2011-15), member of the College \& Research Libraries Editorial Board (2002-08), and as a member of the ALA Committee on Accreditation (2016-20). Parham additionally served as a member of the OCLC Board of Trustees and chair of the OCLC Membership Committee (2012-17), treasurer of the Oberlin Group Consortium (2011-15), and as chair of the Board of Directors and past finance chair of the SOLINET Library Network (2000-04).

Prior to joining the RobertW.Woodruff Library in 2004, Parham served as director of the Hampton University Harvey Library (1998-2004), director/ administrator of the ColonialWilliamsburg Foundation (1997-98), deputy director of the Carnegie Library of Pittsburgh (1991-97), and in a variety of positions at the Chicago Public Library (1977-91). 
nical Services (ALCTS), the Library Leadership and Management Association (LLAMA), and the Library and Information Technology Association (LITA). The award is funded from an endowment established to honor Hugh C. Atkinson.

\section{John Walsh receives CJCLS EBSCO Community College Learning Resources Leadership Award}

John Walsh, director of library services at Cochise College, has received the 2017

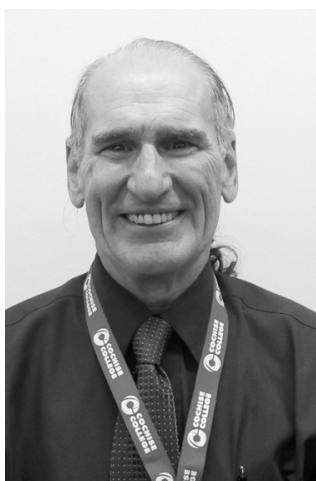

John Walsh Community and Junior College Libraries Section EBSCO Community College Learning Resources Leadership Award.

The $\$ 750$ award and plaque, donated by EBSCO Information Services, will be presented to Walsh at the ALA Annual Conference.

"The committee members were immediately impressed by the ten letters of support that John Walsh received, all of which praised him for the initiative he showed in the creation of a community college consortium in Arizona," said award co-chairs Abbie Basile of Tidewater Community College and Sandra McCarthy of Washtenaw Community College. "The fact that he was successful in bringing every community college together in a consortium to improve library buying power and other collaboration opportunities demonstrates his impressive leadership, communication, and organizational skills. The committee is pleased to offer Walsh this award in recognition of this great achievement."

\section{LDS Business College program wins CJCLS EBSCO Community College Learning Resources Award}

LDS Business College has been chosen to receive the Community and Junior College
Libraries Section EBSCO Community College Learning Resources Award for its "There's a Monster in the Library" program.

The $\$ 750$ award and plaque, donated by EBSCO Information Services, will be presented to Sarah Sorenson, Brandon Bowen, and

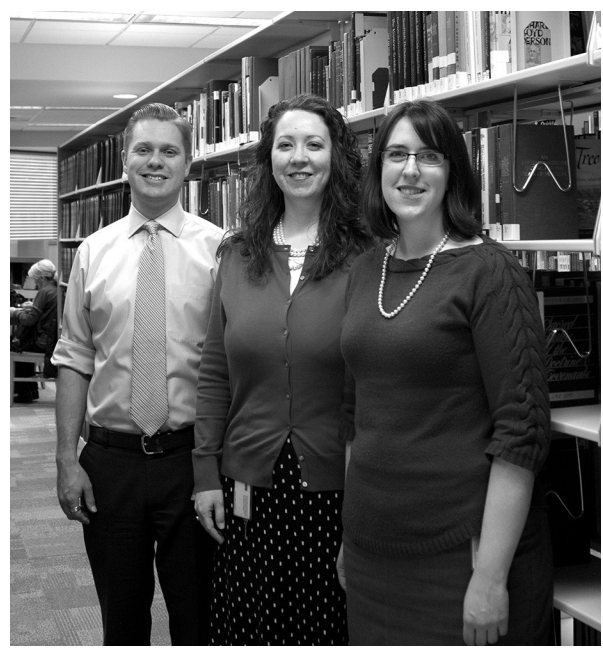

Brandon Bowen, Sarah Sorenson, and Emily Underwood

Emily Underwood of the LDS Business College Library, at the ALA Annual Conference in Chicago. Sorenson is director of learning resources, Bowen is reference and instruction manager, and Underwood is reference and instruction librarian.

"There's a Monster in the Library" is an online tutorial for information literacy instruction stylized as a virtual comic book and using gamification principles and techniques. Three modules, covering search expressions, source evaluation, and the research process, contain active learning integrated with instruction. The tutorial is integrated in the Introduction to College Writing Curriculum with other information literacy assignments and assessments.

"Effective collaboration between libraries and other academic departments can be challenging to achieve, but the librarians at LDS Business College Library have created a healthy, long-term information literacy instruction program with the English 101 instructors," said award co-chairs Sandy Mc- 
Carthy of Washtenaw Community College and Abbie Basile of Tidewater Community College. "The creative, multimodal approach used, including the gamification of online tutorials and active learning activities in faceto-face sessions, demonstrated the librarians' commitment to implementing best practices in instruction. In addition, the librarians' attention to conducting regular assessment and adjusting the instruction accordingly ensures that the program is not only new and interesting, but successful."

\section{Hunter and Riehman-Murphy receive CLS Innovation in College Librarianship Award}

Jennifer Hunter and Christina RiehmanMurphy, reference and instruction librarians at Penn State-Abington, have been named

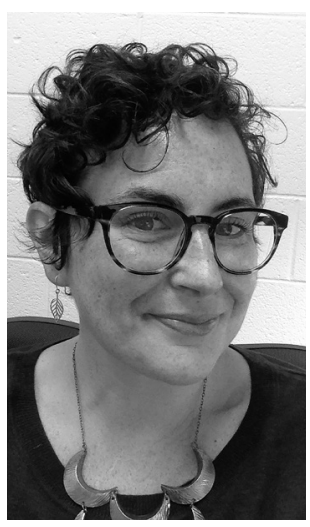

Jennifer Hunter the recipients of the College Libraries Section (CLS) Innovation in College Librarianship Award for their work on the Research Parties and TED Talk as Research Inspiration programs.

This annual award honors ALA members who have demonstrated a capacity for innovation in their work with undergraduates, instructors, and/or the library community.

Their \$1,000 award and plaque, donated by CLS, will be presented during a CLS event at the ALA Annual Conference in Chicago.

"The project was chosen because it represented a new model of instruction composed of two programs: Research Parties and TED Talk as Research Inspiration," said award chair Leah Dunn, university librarian at the University of North Carolina-Asheville. "The program offers a more interactive model of instruction and promotes the library as an integral part of the college's mission by helping them 'forge their own success as productive, responsible, and discerning citizens of a global society.' The nominees created low-tech, high-impact methods of relationship-building that are easily replicated."

Research Parties are drop-in, social rese a r ch

consultation sessions. Like the reference desk, librarians provide inperson help to students from different classes at different stages of

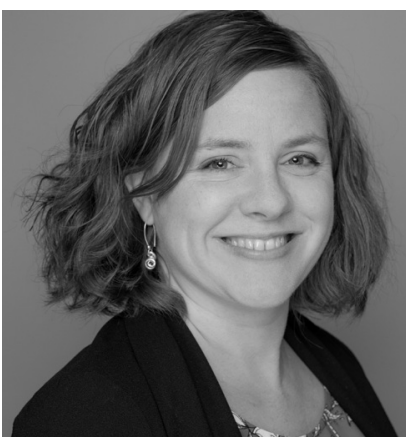

Christina Riehman-Murphy the research

process, but like the hands-on portion of instruction sessions, librarians help multiple students at once, acclimating some students to the databases and then helping others to brainstorm topics or with citations.

TED Talk as Research Inspiration blends a book-club-type environment with instruction. Students view a pre-recorded TED Talk, short lectures delivered by some of the world's most innovative speakers, and the librarians facilitate a discussion about the talk's themes and how students can approach the topic from various disciplinary viewpoints. The group then brainstorms how students might transform the topic of the TED Talk to a topic for their papers or projects.

\section{Blicher wins Routledge Distance Learning Librarianship Conference Sponsorship Award}

Heather Blicher, online learning librarian at Northern Virginia Community College, has been named the recipient of the Routledge Distance Learning Librarianship Conference Sponsorship Award.

This annual award, sponsored by Routledge/Taylor \& Francis Group and administrated by ACRL's Distance Learning Section, honors an ACRL member working in the field of, or contributing to, the success of distance 
learning librarianship or related library service in higher education.

Routledge/Taylor \& Francis Group will present the \$1,200 award and plaque at the

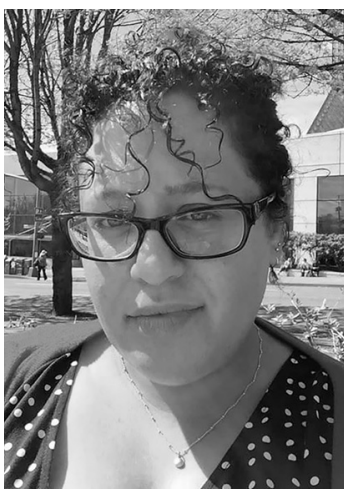

ALA Annual Conference.

"Heather Blicher has proved her dedication to distance librarianship through many professional contributions and service," said award co-chairs Rebecca Nowicki Heather Blicher of Ashford University and Brandon West of the State University of New YorkGeneseo. "As a sole librarian at North Virg in i a Community College, Blicher used technology to coordinate and lead a sustainable embedded librarian program to serve a large student population and was instrumental

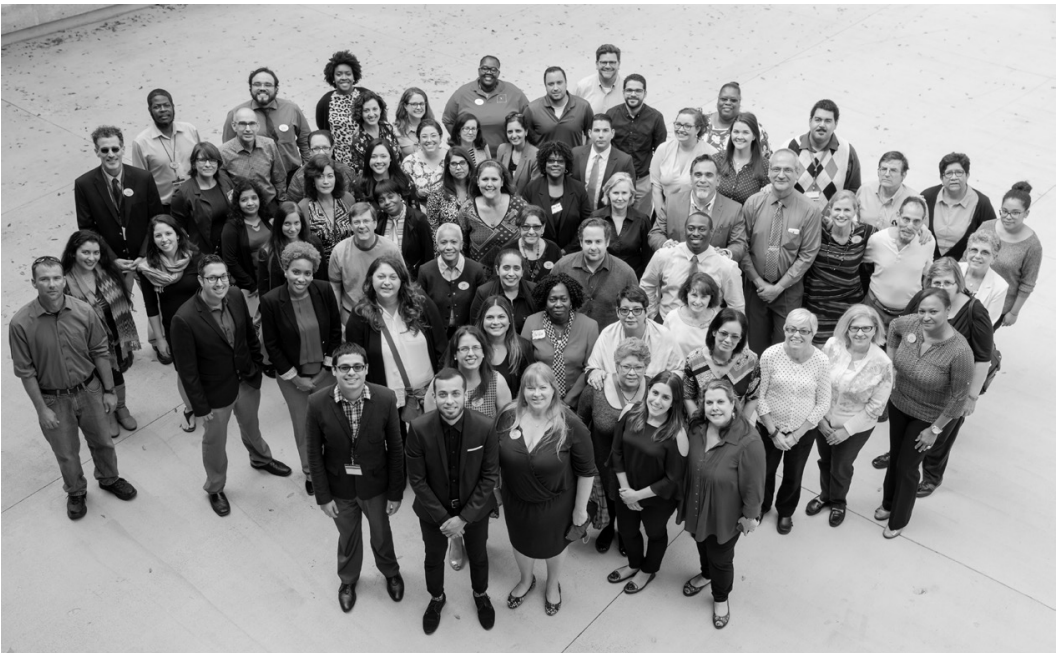
Staff of Learning Resources at Miami Dade College.

in the suc-

cess of the Northern Virginia Community College Open Educational Resources initiatives. We are honored to acknowledge her many contributions to distance learning librarianship."

\section{Excellence in Academic Libraries Award winners}

The recipients of the Excellence in Academic Libraries Award are Miami Dade College-Learning Resources, Miami; Colum- bia College Chicago Library, Chicago; and Santa Clara University Library, Santa Clara, California. Sponsored by ACRL and GOBI Library Solutions from EBSCO, the award recognizes the staff of a college, university, and community college library for programs that deliver exemplary services and resources to further the educational mission of the institution.

"These three deserving recipients demonstrate a commitment to student learning and a user-centered, data-driven approach to developing programs and services, with a focus on campus diversity and creative and transformative services, that exemplifies today's best academic and research libraries," said ACRL Executive Director Mary Ellen K. Davis. "Receiving an Excellence in Academic Libraries Award is a national tribute to each 
of the 2017 Excellence in Academic Libraries Awards Committee and interim vice-president for Information Technology, CIO, and dean of university libraries at the University of Arizona. "The libraries are the heart of student support on campus, housed in Learning Resources along with technology and academic support centers. The committee appreciated their needs assessment, campus collaborations, proactive marketing, strong instruction program, strategic redesign of their learning commons, and embedded librarians, tutors, and technologies."

"This award is a validation and a timely recognition of the valuable work that the Miami Dade College libraries have done over the years to support and enrich the learning process at our institution," said Erick J. Dominicis, college director, learning resources at Miami Dade College. "The award, moreover, corrobo-

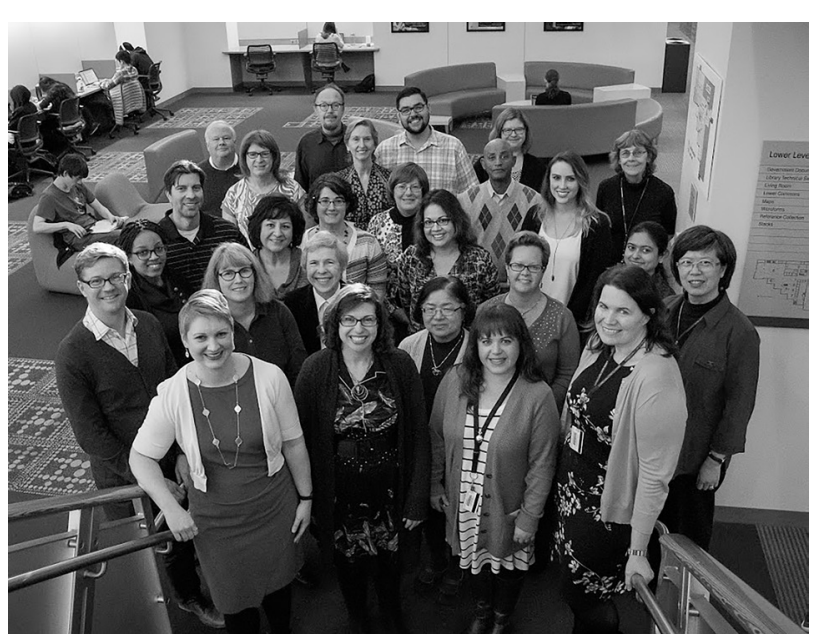

Staff of the Santa Clara University Library. literacy instructional program for the benefit of our students. The ACRL Excellence Award will further motivate librarians and Learning Resources staff to continue the great work
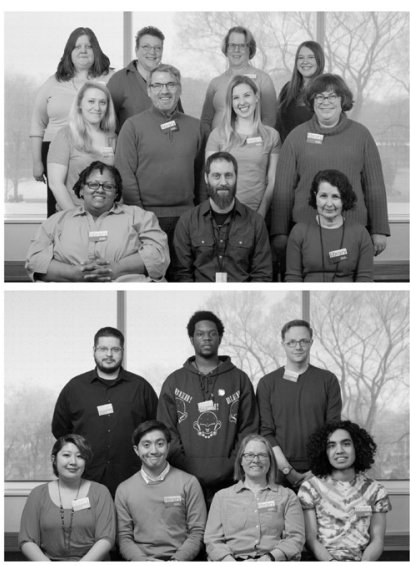

for which they are now recognized."

The Columbia College Chicago Library, winner of this year's award in the college category, was chosen for its creative ways of engaging with the campus community.

"Columbia College Chicago Library is a very different kind of college library," noted Williams. "It is reflective of student culture, and creativity, experimentation, and innovative thinking are paramount. Some of the recent highlights include the Sketchbook Project, the Little Indie Press Festival, the Library Gaming Society, Edible Books, Flying Books, and Frankentoys."

"We also appreciated that all of their programming encourages conversation and interaction among its dirates the im-

portance of the collaboration and partnership developed by the library and the faculty at the college in the development of strong collections and an even stronger information verse, vibrant population," Williams added. "It is a creative and intellectual center for students, faculty, and the broader community alike." 
"I cannot tell you how thrilled I am to learn of this award honoring our innovative and dedicated staff members' good work and the support of our college," said Jan Chindlund, library dean at Columbia College-Chicago. "Our work has evolved over the years; we stand on the shoulders of all who have worked here before to create services, develop collections, engage with our community, and maximize resources. Thank you for this recognition."

The Santa Clara University Library, winner in the university category, was selected for its transformative assessment initiatives to improve library services.

"The committee was impressed by Santa Clara University Library's intentional, usercentered and data-driven approach to their services, collections, and spaces," said Williams. "The library staff actively gather information from students and faculty to drive changes, whether it is through committee participation, focus groups, advisory boards, or surveys. Recent initiatives include a space redesign, a personal librarian service, a robust information literacy program (incorporating Special Collections), and faculty workshop series on integrating research into assignments. They've also made thoughtful improvements to organizational alignment, communication, and culture."

"I was thrilled to receive the news from ACRL President Irene Herold that we were selected as this year's winner," said Jennifer Nutefall, university librarian at Santa Clara University. "Having our transformation recognized through this award by ACRL is deeply meaningful. Our application highlights our transformation which was achieved through forming a cohesive team, working together toward common goals, and fully embodying our ideals of collaboration, dynamic services and collections, and responsiveness to changing student and faculty needs. It is through our amazing staff that we truly live the library's vision to be a 'vibrant and vital center for learning, inspiring both intellectual pursuits and community engagement.' Thank you to the members of the selection committee."
Each winning library will receive $\$ 3,000$ and a plaque, to be presented at an award ceremony held on each recipient's campus.

\section{Gilley wins WGSS Career Achievement Award}

Jennifer Gilley, head librarian at Penn State University-New Kensington, has been selected as the winner of the Women and Gender Studies Section (WGSS) Career Achievement Award. The award honors significant long-standing contributions

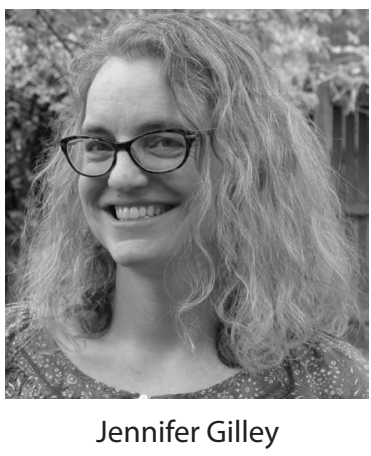
to women's studies in the field of librarianship over the course of a career.

A plaque will be presented to Gilley at a WGSS event during the ALA Annual Conference.

"Jennifer Gilley has demonstrated an illustrious career in women and gender studies librarianship," said award chair Stacy Russo, librarian and associate professor at Santa Ana College. "As a highly dedicated member of the ACRL Women and Gender Studies Section, she has served since 1996 in varying capacities, including chair of the section, chair of the Research Committee, and as a member of the Program Planning Committee. She has also served as the liaison between WGSS and the National Women's Studies Association (NWSA) since 2013. She has been a leader in creating and maintaining WGSS' Research Agenda for Women and Gender Studies Librarianship."

"Gilley has an international reputation in women's studies for her work on feminist publishing and information-seeking behavior in women's studies," continued Russo. "She has presented at numerous conferences in addition to ALA, ACRL, and NWSA, including the 15th International Confer- 
ence on Books in London and Publishing Feminisms Symposium in Canada. Her writing has appeared in Reference $\&$ User Services Quarterly; American Libraries; The International Journal of the Book; National Women's Studies Association Journal; and Frontiers: A Journal of Women's Studies.

Gilley's essay "Feminist Publishing/ Publishing Feminism: Experimentation in Second Wave Book Publishing" is the lead chapter in This Book is an Action: Feminist Print Culture and Activist Aesthetics (University of Illinois Press, 2016), which was a CHOICE Outstanding Academic Title for 2016."

"At the Penn State-New Kensington campus, Gilley has served as the liaison to Penn State University's Commission for Women for the past decade," said Russo. "She has received numerous awards for research development from Penn State University, the Sallie Bingham Center for Women's History and Culture, the Schlesinger Library on the History of Women in America at the Radcliffe Institute for Advanced Study at Harvard University, and other organizations. Her career accomplishments in women and gender studies librarianship are inspiring, exceptional, and unwavering."

\section{Weaver wins WGSS Significant Achievement Award}

Janet Weaver, assistant curator of the Iowa Women's Archives at the University of Iowa, is the winner of the Women and Gender Studies Section (WGSS) Award for Significant Achievement in Woman's Studies Librarianship. The WGSS award honors a significant or one-time contribution to women's studies librarianship.

A plaque will be presented to Weaver at a WGSS event during the ALA Annual Conference in Chicago.

"The Awards Committee was greatly impressed by Weaver's creation of the Migration is Beautiful website, which is a project constructed from oral histories and other archival material housed at the Iowa Women's Archives," said award chair Stacy Russo, librarian and associate professor at Santa Ana College. "Migration is Beautiful was developed from the Iowa Women's Archives' Mujeres Latinas project that launched in 2005. The committee especially noted Weaver's level of collaboration with her colleagues and undergraduate students. The students selected documents for the website and also wrote vignettes. The introduction on the website reads: 'Migration is Beautiful highlights the contributions Latinas

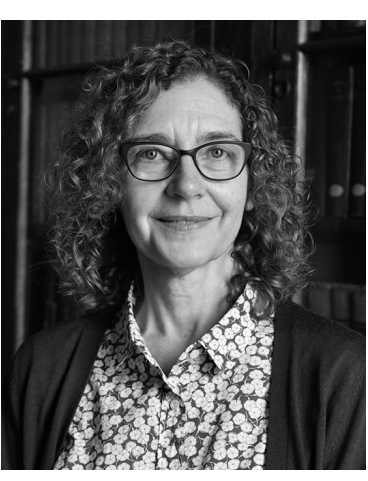

Janet Weaver and Latinos have made to Iowa history. Migration is central to understanding and interpreting the past, shaped first by Native Americans, and later by immigrants from around the world."”

The Migration is Beautiful digital humanities project highlights the contributions of Latinas, their families, and their organizations to Iowa history. Visitors can navigate the site in multiple ways to access hundreds of digitized primary documents and audio clips from oral history interviews through historical topics, life stories, and a migration map.

"Weaver's work has brought accessibility to primary source documents that were previously only available to visitors at the Iowa Women's Archives," continued Russo. "After its launch in 2016, Migration is Beautiful debuted with a travelling exhibit at the national League of United Latin American Citizens convention in Washington, D.C. In her continued emphasis on outreach, Weaver has made presentations to Latino groups around Iowa regarding the project. Her work has also been featured on Hola Iowa, a news outlet that focuses on Latinos in the Midwest." $\mathbf{n}$ 